\title{
Jerzy Adamczyk
}

„Uwaga bomba!”

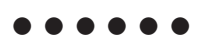

opracowanie

Marcin Adamczyk ${ }^{1}$

[Wrocław]

Wrocławski Rocznik

Historii Mówionej

Rocznik VIII, 2018

ISSN 2084-0578

DOI: $10.26774 /$ wrhm.203

Relacja Jerzego Adamczyka zarejestrowana została przez autora niniejszego opracowania $^{2}$ na przełomie 2005/2006 r. w celu zachowania rodzinnej pamięci. Impulsem do opublikowania jej drukiem jest przypadająca w tym roku dziesiąta rocznica śmierci świadka, który zmarł po ciężkiej chorobie 3 lutego $2008 \mathrm{r}$. Opracowanie zawiera krótkie wprowadzenie, opisujące losy Jerzego Adamczyka przed okresem opowiedzianym w relacji. Starano się je odtworzyć na podstawie wspomnień młodszego brata Jerzego, Zdzisława, które zostały spisane w sierpniu $2018 \mathrm{r}$. i znajdują się w posiadaniu autora, biogramu zamieszczonego w publikacji Pro memoria. Bohaterowie Solidarności Walczacej autorstwa Małgorzaty Wanke-Jakubowskiej i Marii Wanke-Jerie ${ }^{3}$ oraz redagowanej przez Instytut Pamięci Narodowej (IPN) i dostępnej on-line Encyklopedii Solidarności ${ }^{4}$. W samej, blisko godzinnej rozmowie wyróżnić można cztery części: najpierw Jerzy Adamczyk opowiada o swojej pracy

\footnotetext{
https://orcid.org/oooo-0oo2-3432-0358.

Bratanka Jerzego Adamczyka.

3 M. Wanke-Jakubowska, M. Wanke-Jerie, Pro memoria. Bohaterowie Solidarności Walczacej, Wrocław 2017.

4 Zob.: http://www.encysol.pl/wiki/Strona_g\%C5\%82\%C3\%B3wna (dostęp: 28 I 2019 r.).
} 
w Wojewódzkim Przedsiębiorstwie Handlu Wewnętrznego we Wrocławiu $(\mathrm{WPHW})^{5}$ i utworzeniu w nim niezależnego związku zawodowego, następnie opisuje to, jak zapamiętał 13 grudnia $1981 \mathrm{r}$. oraz jak wprowadzenie stanu wojennego bezpośrednio wpłynęło na losy jego i zakładu pracy - wspomina przy tym zarówno momenty komiczne, jak i dramatyczne. W kolejnej części opowiada historię założenia wraz z kolegami podziemnego wydawnictwa ${ }^{6}$, a następnie podsumowuje swoje wspomnienia gorzką refleksją na temat współczesnych losów znanych mu działaczy antykomunistycznych i tego, jak zostali potraktowani ci, którzy w stanie wojennym walczyli o wolny kraj, często - jak wspomina - tracąc z tego powodu pracę i zdrowie.

Opracowując relację do publikacji, autor dokonał niezbędnej redakcji językowej, gdzieniegdzie wyeliminował powtórzenia czy zbędne wyrazy (typowe dla języka mówionego), a także, aby tekst stał się bardziej spójny, zamieścił w nawiasach kwadratowych własne dopowiedzenia i adnotacje na temat emocji, jakie świadek przejawiał w trakcie wywiadu. Treść opatrzono przypisami rzeczowymi, objaśniającymi kontekst lub szczegóły wypowiedzi świadka, oraz bibliograficznymi, odsyłającymi do szerszej literatury przedmiotu na dany temat.

Kluczowym tematem niniejszej relacji jest sposób funkcjonowania podziemnych wydawnictw i drukarni w PRL. Kamil Dworaczek wskazuje, że ich rozwój związany był z wydarzeniami czerwca 1976 , które stały się katalizatorem powstania zorganizowanej opozycji w komunistycznej Polsce ${ }^{8}$. Po podpisaniu tzw. porozumień sierpniowych w 1980 r. ${ }^{9}$ ówczesna opozycja antykomunistyczna rozpoczęła wydawanie książek i czasopism na dużą

$5 \quad$ Wojewódzkie Przedsiębiorstwo Handlu Wewnętrznego we Wrocławiu z siedzibą przy ul. Rzeźniczej 1 istniało do $1983 \mathrm{r}$.

$6 \quad$ Ten wątek w niniejszym opracowaniu został złożony z dwóch osobnych fragmentów opowieści, gdyż Jerzy Adamczyk wrócił później jeszcze do tematu drukarni, uzupełniając go o ciekawe informacje.

$7 \quad$ Chodzi o krwawo stłumione protesty robotnicze przeciwko drastycznej podwyżce cen w Radomiu, Ursusie i Płocku; zob.: J. Eisler, Polskie miesiace, czyli kryzys(y) w PRL, Warszawa 2008, s. 44 i nn.; P. Sasanka, Czerwiec 1976. Geneza, przebieg, konsekwencje, Warszawa 2006.

$8 \quad$ K. Dworaczek, Podziemne drukarstwo we Wrocławiu na przykładzie największych inicjatyw wydawniczych, „Dzieje Najnowsze”, t. 48 (2016), nr 4, s. 141.

$9 \quad$ Władze PRL zobowiązały się w nich m.in. do ograniczenia cenzury; zob.: L. Biernacki, A. Kazański, NSZZ, Solidarność” Region Gdański, [w:] NSZZ, Solidarność” 1980-1989. T. 3, Polska pótnocna, red. Ł. Kamiński, G. Waligóra, Warszawa 2010, s. 28-29; G. Waligóra, Opozycja polityczna na Dolnym Śląsku 1975-1980, Wrocław 2016, s. 147. 
skalę. Dworaczek wskazuje, iż w roku 1981 ukazało się 1896 czasopism, a w latach 1980-1981 wydano ponad tysiąc książek. Wprowadzenie stanu wojennego $^{10}$ znacznie ograniczyło niezależną działalność wydawniczą - w $1982 \mathrm{r}$. wydano już tylko 954 różne czasopisma, a liczba ta malała aż do roku 1986, w którym ukazały się zaledwie 552 tytuły. Od 1987 r. dało się zauważyć wyraźny trend wzrostowy, którego ukoronowaniem było osiągnięcie dwa lata później liczby przeszło 1200 niezależnych czasopism. Łącznie w latach 1976-1990 wydawanych było ponad 5500 czasopism i opublikowano 6500 tytułów książkowych ${ }^{11}$. Należy przy tym pamiętać, jak skomplikowaną operacją było uruchomienie podziemnej drukarni oraz jak trudne i niebezpieczne były warunki pracy drukarzy i innych osób związanych z działalnością wydawniczą ${ }^{12}$. Niezbędny był bezpieczny lokal, którym najczęściej zostawało mieszkanie osoby luźno związanej z opozycją, budynki gospodarcze, specjalnie w tym celu wybudowane, ukryte pomieszczenia czy nawet podziemne bunkry ${ }^{13}$. Lokale takie musiały być często zmieniane, aby Służba Bezpieczeństwa nie wpadła na trop drukarni. Samo drukowanie wymagało od drukarza nie tylko odpowiedniej wiedzy i umiejętności, ale również odporności psychicznej i fizycznej - obsługiwanie powielaczy wymagało kilkunastu, a czasem nawet kilkudziesięciu godzin ciężkiej pracy w szczelnie zamkniętym pomieszczeniu, w którym dokuczał zapach farby i hałas $^{14}$ i istniało ciągłe zagrożenie wpadką i aresztowaniem przez $\mathrm{SB}^{15}$. Jeśli chodzi o sprzęt do drukowania, to wykorzystywano praktycznie

10 Zob. m.in.: A. Paczkowski, Wojna polsko-jaruzelska. Stan wojenny w Polsce 13 XII 1981 - 22 VII 1983, Warszawa 2006; Stan wojenny w Polsce. Kalendaria wydarzeń 13 XII 1981 - 31 XII 1982, red. W. Chudzik, Warszawa 1999.

11 K. Dworaczek, op. cit., s. 142.

12 Więcej na ten temat zob.: J. Olaszek, Podziemne dziennikarstwo. Funkcjonowanie gtównych pism informacyjnych podziemnej „Solidarności” w Warszawie w latach 1981-1989, Warszawa 2018, s. 413 i nn.

13 Zob.: Techniki powielania na przykładzie „Biuletynu Dolnośląskiego”, http://www. sw.org.pl/techniki.html (dostęp: 28 I 2019 r.); W. Polak, Od dziecięcej drukarenki do offsetu. Krótka historia niezależnej poligrafii w Toruniu, „Biuletyn Instytutu Pamięci Narodowej”, nr 7 (66) (2002), s. 80; Drukarnia „Wilno” im. gen. L. Okulickiego „Niedźwiadka”, http://www.encysol.pl/wiki/Drukarnia_Wilno_im._gen._L._Okulic kiego_\%E2\%80\%9ENied\%C5\%BAwiadka\%E2\%80\%9D (dostęp: 28 I 2019 r.).

$14 \quad$ Zob.: Techniki powielania...

15 Zob.: J. Olaszek, Dokumenty Stużby Bezpieczeństwa jako źródło do badania historii prasy podziemnej (wybrane przykłady), [w:] Letnia Szkoła Historii Najnowszej 2010. 
wszystko, co się do tego nadawało: od prostych powielaczy domowej roboty (z matrycami białkowymi) i samodzielnie skonstruowanych maszyn drukarskich, przez profesjonalne powielacze przemycane $\mathrm{z}$ Zachodu ${ }^{16}$, po dostępne już w latach 8o. maszyny offsetowe, kserografy czy nawet pierwsze igłowe drukarki komputerowe ${ }^{17}$. Na bieżąco należało też pozyskiwać farbę drukarską oraz znaczne ilości papieru, a obu tych materiałów w sklepach brakowało tak samo, jak i innych podstawowych towarów. Ich sprzedaż ponadto często bywała reglamentowana i kontrolowana, z czym radzono sobie, dokonując licznych pojedynczych zakupów, a czasem udawało się kupić nielegalnie lub ukraść większą ilość papieru wprost z transportu lub bezpośrednio z legalnej drukarni ${ }^{18}$. Kwestią nie mniej ważną była też dystrybucja wydrukowanych publikacji, które za pomocą sieci kontaktów przekazywano w małych pakietach kurierom, a ci zazwyczaj dystrybuowali je następnie w swoim otoczeniu ${ }^{19}$. Działalność jednej tylko podziemnej drukarni, która wydawała zwykle nie więcej niż jedno czasopismo (czasem również drukowała książki), wymagała zatem zaangażowania przynajmniej kilkunastu osób (drukarzy, właścicieli lokalów, kurierów i kolporterów ${ }^{20}$ ). Biorąc pod uwagę ogólną liczbę niezależnych tytułów prasowych, które ukazywały się

Referaty, red. N. Jarska, T. Kozłowski, Warszawa 2011, s. 233-234.

16 K. Grzelczyk, Solidarność drukująca. Wrocławscy drukarze podziemni, Wrocław 2013, s. 134 i nn.

17 Zob.: J. Olaszek, G. Wołk, Drugi obieg wydawniczy w oczach Stużby Bezpieczeństwa, „Pamięć i Sprawiedliwość”, nr 1 (21) (2013), s. 391 i nn.; Techniki powielania...; K. Dworaczek, op. cit., s. 152; W. Polak, op. cit., s. 70 i nn.; L. Ziątkowski, Na drodze do Solidarności. Wrocław w walce o demokrację i niepodlegtość 1976-1980, Wrocław 2010, s. 67-71, 129-130.

18 Zob.: Techniki powielania...; K. Dworaczek, op. cit., s. 151.

19 Zob.: J. Olaszek, G. Wołk, op. cit., s. 416 i nn.; K. Dworaczek, op. cit., s. 147 i nn.; M. Bosacka, Czasopisma drugiego obiegu w zbiorach Biblioteki Uniwersyteckiej we Wroctawiu, „Bibliotheca Nostra. Śląski kwartalnik naukowy”, nr 2 (2013), s. 67; J. Olaszek, Dokumenty Stużby Bezpieczeństwa..., s. 234-235.

20 Warto pamiętać, że niektóre drukowane w podziemiu czasopisma rozpowszechniane były nie tylko w kraju, ale i za granicą (por.: P. Urbaniak, Literackie pisma bezdebitowe we Wrocławiu w latach 1976-1989, „Rocznik Historii Prasy Polskiej”, t. 14 (2011), zeszyt 1-2, s. 194), a nakłady innych sięgały nawet kilkudziesięciu tysięcy egzemplarzy każdego numeru: Ł. Kamiński, Krasnoludki i żotnierze. Wrocławska opozycja lat osiemdziesiątych, „Pamięć i Przyszłość”, nr 2 (2008), s. 8; K. Grzelczyk, op. cit., s. 62 i nn. 
w PRL, można przyjąć, że z podziemnym drukarstwem mogło być związa-

nych nawet kilkadziesiąt tysięcy osób, przy czym część osób była związana $\mathrm{z}$ więcej niż jedną drukarnią.

Jerzy Adamczyk urodził się 10 maja 1948 r. w Chobieni na Dolnym Śląsku jako czwarty z pięciorga rodzeństwa (miał trzy starsze siostry - Alinę, Leokadię i Zofię oraz wspomnianego młodszego brata) ${ }^{21}$. W 1964 r. wyjechał do Wrocławia, gdzie podjął pracę w Przedsiębiorstwie Budownictwa Ogólnego $^{22}$ jako cieśla i na tym stanowisku pracował do 1977 r. W międzyczasie ukończył liceum ogólnokształcące dla dorosłych oraz Policealne Studium Budownictwa Ogólnego ${ }^{23}$. W 1978 r. podjął pracę w WPHW, gdzie rozpoczęła się jego działalność opozycyjna. Jerzy Adamczyk w swojej relacji nie wspomina przy tym, że od 1983 r. był członkiem Solidarności Walczącej, a na przełomie 1988/89 roku brał udział w reaktywowaniu struktur „Solidarności” w Przedsiębiorstwie Handlu Artykułami Wyposażenia Mieszkań „Domar” we Wrocławiu ${ }^{24}$, gdzie pracował od 1982 r. $^{25}$ Według Zdzisława Adamczyka tradycje walki o wolną Polskę były w rodzinie żywe: „Nasz dziadek od strony matki walczył w Legionach, zaś wujek służył w partyzantce na Kielecczyźnie, gdzie zginął w walkach z Niemcami o most"26, i były bliskie Jerzemu Adamczykowi.

21 Rodzice, Genowefa i Wincenty, do Chobieni sprowadzili się tuż po wojnie, wcześniej mieszkali w Skarżysku-Kamiennej, a następnie w Czerwińsku (lub Czerwieńsku).

22 Wrocławskie Przedsiębiorstwo Budownictwa Ogólnego przy ul. Sądowej 2 we Wrocławiu było jednym z kilku dużych przedsiębiorstw budowlanych w stolicy Dolnego Śląska.

23 Nie udało się ustalić więcej szczegółów na ten temat.

24 Przedsiębiorstwo z siedzibą przy ul. Wita Stwosza 12 we Wrocławiu przetrwało do prywatyzacji na początku lat 9o. XX w.; zob. http://www.firma.egospodarka.pl/ zlikwidowane/przedsiebiorstwo-handlu-artykulami-wyposazenia-mieszkan-domar,wroclaw,13235.html (dostęp: 28 I 2019 r.).

25 M. Wanke-Jakubowska, M. Wanke-Jerie, op. cit., Wrocław 2017, s. 9-10; http://www. encysol.pl/wiki/Jerzy_Adamczyk (dostęp: 23 IX 2018 r.).

26 Bliższe szczegóły tego wydarzenia nie są znane. 


\section{Relacja Jerzego Adamczyka}

\section{Sierpień 1980 i powstanie Solidarności}

Przed stanem wojennym pracowałem w Wojewódzkim Przedsiębiorstwie Handlu Wewnętrznego jako specjalista ds. inwestycji ${ }^{27} \mathrm{w}$ dziale inwestycji na ul. Rzeźniczej we Wrocławiu. [Była to] bardzo ciekawa praca - przygotowywanie jakichś nowych obiektów, handlowych przede wszystkim. Przygotowywaliśmy m.in. rozbudowę na ul. Zielińskiego. Miał tam powstać duży dom handlowy, 40 ooo $\mathrm{m}\left[{ }^{2}\right]$, ale to wszystko były takie wizje komunistyczne, które praktycznie tylko kończyły się na papierze, czyli ludzie projektowali w Warszawie, bo biuro projektowe było w Warszawie, więc [odbywaliśmy] częste wyjazdy w delegacje do biura projektowego. To było [biuro projektowe] branżowe dla handlu. Przyjemności dużo, a tu we Wrocławiu realizowało się niewiele. Między innymi robiliśmy tam pawilon „Huby” na ul. Św. Jerzego ${ }^{28}$. To była jedna z tych inwestycji, które robiłem. Robiliśmy, tam w tej chwili jest pani Piaseckiej-Johnson ${ }^{29}$ taka hala targowa [lub] hala magazynowa - na ulicy... chyba to była Kozia ${ }^{30}$. No to były mniej więcej takie rzeczy przed stanem wojennym, [jakie] realizowałem jako specjalista ds. inwestycji, no wspólnie z kolegami w dziale. Mieliśmy bardzo dużo czasu, bo można było rzeczywiście wychodzić z pracy, kiedy się chciało, jak się chciało. No bo wiadomo: kontakty z różnymi instytucjami typu wydział architektury, budownictwa itd. Więc kontakty były nawiązywane z ludźmi różnymi, tak że ta praca wzbogacała.

Według Pro memoria..., s. 9, oraz Encyklopedii Solidarności, http://www.encysol.pl/ wiki/Jerzy_Adamczyk (dostęp: 23 IX 2018 r.) było to stanowisko pracownika nadzoru BHP, a następnie inspektora BHP. Według Zdzisława Adamczyka było to stanowisko specjalisty ds. inwestycji. Możliwe, że świadek pełnił wówczas również funkcję społecznego inspektora pracy i stąd powyższa rozbieżność. Budynek znajdujący się na rogu wspomnianych ulic św. Jerzego i Hubskiej we Wrocławiu, w latach 8o. XX w. służył jako sklep z wyposażeniem wnętrz. W latach 90. został przekształcony w halę targową.

29 Chodzi o Barbarę Piasecką-Jonhson (1937-2013), główną spadkobierczynię jednego ze współwłaścicieli globalnego koncernu Johnson\&Johnson, związaną z Wrocławiem i Dolnym Śląskiem; zob.: Barbara Piasecka Johnson, https://www.telegraph.co.uk/ news/obituaries/9975192/Barbara-Piasecka-Johnson.html, (dostęp: 28 I 2019 r.). 
W związku z tym, że miałem te kontakty, to bardzo łatwo w momencie, kiedy w [19]80 r. postulaty ukazały się w Gdańsku i Gdyni ${ }^{31}$, więc miałem chyba [jako] jeden z pierwszych - przynajmniej u siebie w firmie na pewno pierwszy - otrzymałem te postulaty, bo miałem kontakty z ludźmi, którzy po prostu mieli [je] wcześniej - wracali z wczasów czy coś. To było akurat w momencie, kiedy ja wróciłem z wczasów i również bardzo dużo ludzi powracało, bo to była połowa mniej więcej sierpnia. Więc te postulaty jako jeden z pierwszych zawiesiłem u siebie w zakładzie pracy - to były nawiasem mówiąc szczecińskie postulaty, nie gdańskie ${ }^{32}$. No ale co chwilę ktoś tam je zrywał, ale jednak na bieżąco myśmy przepisywali je na maszynie i wieszali. Mieliśmy z tego tytułu jakieś tam nieprzyjemności, ale nie były to nieprzyjemności duże, bo ludzie już wiedzieli, że coś się dzieje nie tak, więc w pewnym momencie już właściwie jakby zaakceptowali, że te postulaty mogą wisieć, bo one były wieszane w takich specjalnych gablotach przed wejściem. Natomiast te gabloty były wcześniej zamykane. No ale gdzieś tam udało się nam klucz dostać do którejś z tych gablot. Bo to były różne [gabloty] branżowe, związki [je] miały ${ }^{33}$ i inne. Tośmy tam zawiesili i zamknęli na własną kłódkę, no i jakiś czas wisiały te postulaty. No i w którymś momencie, kiedy już zaczęły być te strajki we Wrocławiu ${ }^{34}$, to właściwie nikt już nie zrywał. W tym momencie praktycznie postulaty były ogólnie dostępne,

31 Zob. przyp. 8.

32 Postulaty szczecińskie w dużej mierze pokrywały się z gdańskimi, choć jednocześnie w wielu obszarach szły dalej, m.in. w kwestii dostępu do transmisji mszy świętej za pośrednictwem środków masowego przekazu: Ł. Kamiński, Dekada „Solidarności”, „Biuletyn Instytutu Pamięci Narodowej”, nr 9-10 (2010), s. 2. Pełną treść postulatów szczecińskich zob.: https://pl.wikisource.org/wiki/36_postulat\%C3\%B3w_ Mi\%C4\%99dzyzak\%C5\%82adowego_Komitetu_Strajkowego_w_Szczecinie (dostęp: 23 IX 2018 r.).

33 Chodzi o podporządkowane władzy związki zawodowe działające w ramach Zrzeszenia Związków Zawodowych na podstawie ustawy z dnia 1 lipca 1949 r. o związkach zawodowych, Dz.U. 1949 nr 41 poz. 293; por.: B. Rydz, Organizacja terenowych struktur związków zawodowych w południowych powiatach województwa lubelskiego $w$ latach 1944-1975, „Radzyński Rocznik Humanistyczny”, t. 10 (2012), s. 92-95.

34 Strajki we Wrocławiu zaczęły się 26 VIII 1980 r., czyli 12 dni po rozpoczęciu strajków na Wybrzeżu, i były to pierwsze wówczas strajki poza samym Wybrzeżem. Za symboliczny początek wrocławskiego strajku uznaje się zablokowanie dwoma autobusami wyjazdu z zajezdni nr VII przy ul. Grabiszyńskiej; Ł. Sołtysik, Solidarność w „Polarze”, Wrocław 2016, s. 44-45; W. Suleja, „Solidarnośc” na Dolnym Śląsku 1980-2010, Wrocław 2010, s. 38-39. 

pismach, co w jakiś takich bezdebitowych wydawnictwach ${ }^{36}$, ulotkach, które po prostu rozdawali, głównie ci z MPK ${ }^{37}$ ludzie, no bo tam była, że tak powiem, ta działalność największa - w tych zajezdniach ${ }^{38}$. No i w niektórych

35 Między innymi w specjalnym wydaniu „Biuletynu Dolnośląskiego”; oraz na ulotce zatytułowanej Do robotników Dolnego Ślaska; G. Waligóra, op. cit., s. 148-149. Mowa o publikacjach wydawanych bez zgody urzędu cenzury (zwanej debitem). Wydawał je Główny Urząd Kontroli Prasy, Publikacji i Widowisk, a od lipca 1981 r. - Główny Urząd Kontroli Publikacji i Widowisk, mieszczący się przy ul. Mysiej 5 w Warszawie. W każdym z 49 województw działały oddziały terenowe GUKPiW; Cenzura w PRL. Relacje historyków, red. Z. Romek, Warszawa 2010; T. Strzyżewski, Wielka księga cenzury PRL $w$ dokumentach, Warszawa 2015; A. Dombska, Ograniczenia wolności prasy w PRL, „Studia Prawno-Ekonomiczne”, t. LXXXIV (2011), s. 79-100; W. Zakrzewski, O ingerencji prawodawczej $w$ wolność słowa $w$ okresie PRL, "Studia Iuridica Lublinensia”, nr 22 (2012), s. 631-655; G. Łęcicki, Cenzura w Polsce Ludowej: propaganda, manipulacja, destrukcja, „Kwartalnik Nauk o Mediach”, nr 2 (2015): http://knm.uksw.edu.pl/cenzura-w-polsce-ludowej-propaganda-manipulacja-destrukcja/ (dostęp: 3 V 2019 r.).

Chodzi o Miejskie Przedsiębiorstwo Komunikacji we Wrocławiu, działające nieprzerwanie od 1951 r.; Ł. Wolniewicz, Historia tramwajów we Wroctawiu 1945-2015, wykład: https://wroclawskakomunikacja.pl/biezace-wiadomosci/54-aktualnosci/1167-historia-tramwajow-we-wroclawiu-1945-2015-wyklad (dostęp: 28 I 2019 r.).

38 Jak już wcześniej wspomniano, we Wrocławiu w sierpniu 1980 r. strajki solidarnościowe z Wybrzeżem zaczęły się w Zajezdni MPK nr 7 przy ul. Grabiszyńskiej (rano 26 sierpnia) i do południa rozszerzyły na pozostałe oddziały przedsiębiorstwa (według relacji Tomasza Surowca, kierowcy MPK i jednego z inicjatorów strajku, informacje były roznoszone przez łączników; por.: K. Białkowski, Człowiek, który zatrzymat Wroctaw, https:// www.gosc.pl/doc/1673297.Czlowiek-ktory-zatrzymal-Wroclaw (dostęp: 4 V 2019 r.). W obliczu blokady informacyjnej nałożonej przez władze (w mediach strajki określano mianem „przerw [lub „przestojów”] w pracy”) całkowite zatrzymanie komunikacji miejskiej było wyraźnym sygnałem dla mieszkańców miasta, iż strajki dotarły do Wrocławia; W. Kucharski, Centrum Historii Zajezdnia we Wrocławiu. Albo: jak porwać opowieścia o historii miasta, https://wszystkoconajwazniejsze.pl/wojciech-kucharski-centrum-historii-zajezdnia-we-wroclawiu-albo-jak-porwac-opowiescia-o-historii-miasta/ (dostęp: 3 V 2019); L. Ziątkowski, Na drodze do Solidarności..., s. 85-86; idem, Na drodze do wolności. Solidarny Wrocław sierpień 1980 - grudzień 1981, Wrocław 2011, s. 6; W. Suleja, op. cit., s. 36 i nn. Podobny efekt udało się wcześniej osiągnąć w Warszawie, gdzie strajk komunikacji miejskiej zaczął się już 11 sierpnia, czy w Trójmieście (od 15 sierpnia); J. Eisler, op. cit., s. 51; A. Kazański, Sierpień '8o w Gdańsku, „Biuletyn Instytutu Pamięci Narodowej”, nr 9-10 (2010), s. 25 i nn.; idem, Sierpień '8o w Gdyni, „Biuletyn Instytutu Pamięci Narodowej", nr 9-10 (2010), s. 49 i nn. 
fabrykach też już były strajki ${ }^{39}$, natomiast w naszym zakładzie strajku jako takiego nie było ${ }^{40}$.

[...] [Po podpisaniu porozumień sierpniowych] założyłem u nas „Solidarność" w pracy. Założyłem na tej zasadzie, że firma miała tak jakby pięć zakładów. No tak praktycznie zostałem wyłoniony w drodze jakiejś takiej bez wyborów. Po prostu ktoś, [inni] poczuli, że ja mogę być przywódcą tego jednego oddziału, czyli zarządu firmy. Poza tym były oddziały, gdzie zajmowali się usługami, niektórzy handlem typu RTV AGD, itd. itd. No więc z tego tytułu zrobiliśmy zebranie załogi. Właściwie to było z inicjatywy dyrekcji, bo w momencie, kiedy już te strajki upadły ${ }^{41}$, to można było oficjalnie w zakładach pracy zgłaszać postulaty. No i ludzie różne takie postulaty zgłaszali i te postulaty trzeba było po prostu w jakiś sposób sprecyzować. Więc dyrekcja postanowiła zrobić zebranie z załogami poszczególnych oddziałów, no i między innymi w moim zakładzie jako dyrekcji, w ostatnim już w firmie, przeprowadzili zebranie z załogą. Można było zgłaszać postulaty, również wcześniej [jak] ludzie zgłaszali, to te postulaty były na piśmie wszystkie odnotowywane. Zorganizowaliśmy taką grupę, parę osób i te postulaty dziewczyny tam pospisywały. Część ludzi na zebraniu też jakieś swoje postulaty zgłaszała. Z tym, że to było takie zebranie typu dyrektor, sekretarz partyjny ${ }^{42}$, organizacje młodzieżowe itd.

39 Zdaniem autora bliskie sąsiedztwo wielu zakładów produkcyjnych Wrocławia (o których Jerzy Adamczyk wspomina w dalszej części relacji) mogło sprzyjać bliskim kontaktom pomiędzy robotnikami i w efekcie szybkiemu rozszerzeniu się sierpniowych strajków w pierwszej kolejności na te przedsiębiorstwa - co potwierdzać może fakt, iż we wrocławskiej fabryce „Polar” (która znajdowała się na przeciwległym krańcu miasta) strajki wybuchły dzień później; zob. Ł. Sołtysik, op. cit., s. 44-45.

40 Por. M. Wanke-Jakubowska, M. Wanke-Jerie, op. cit., s. 9 oraz http://www.encysol.pl/ wiki/Jerzy_Adamczyk (dostęp: 23 IX 2018 r.), gdzie mowa o tym, że Jerzy Adamczyk był organizatorem strajków w WPHW w sierpniu 1980 r. W opinii autora wypowiedź świadka wskazuje raczej na niepokoje wśród załogi (w dalszej części mowa jest o zgłaszaniu postulatów), które dyrekcja starała się zneutralizować, organizując spotkania z pracownikami poszczególnych oddziałów firmy.

${ }^{41}$ Chodzi zapewne o zakończenie strajków w wyniku podpisania porozumień sierpniowych.

42 Chodzi o sekretarza stojącego na czele Podstawowej Organizacji Partyjnej (POP), najmniejszej jednostki PZPR, liczącej przynajmniej pięciu członków, tworzonej praktycznie we wszystkich zakładach pracy i instytucjach od 1949 r.; D. Magier, Podstawowe organizacje partyjne w systemie biurokratycznym Polskiej Zjednoczonej Partii Robotniczej, [w:] Dzieje biurokracji, t. 4, red. A. Górak, K. Latawiec, D. Magier, 
Ale w związku z tym, że ja tak byłem wyłoniony jako przewodniczący nieformalny, bo nie było takiego czegoś [jak instytucja przewodniczącego], nikt mnie nie nazywał przewodniczącym, ale ja prowadziłem to zebranie. Więc ja prowadziłem to zebranie $\mathrm{z}$ ramienia tej [organizacji] - znaczy nikt tego nie nazywał dokładnie, że ten związek będzie się nazywał „Solidarność" - niezależny związek, jako niezależny związek. To myśmy [pracownicy WPHW] to zorganizowali. Była dość poważna afera, bo na tym moim zebraniu m.in. wytknięto pierwszemu sekretarzowi zakładowej organizacji partyjnej, że on zakwestionował powstanie niezależnych związków zawodowych. Bardzo mocno tam na niego załoga napadła - no może nie cała załoga, ale parę osób próbowało mu wytknąć jego niewłaściwe zachowanie, bo tym bardziej, że już praktycznie zostało to [porozumienie] podpisane przez władze państwowe, a on się nie chciał zgodzić. No i tak powstał ten u nas Związek Zawodowy „Solidarność”. Bo w którymś momencie ogłosiliśmy go jako Niezależny Samorządny Związek Zawodowy „Solidarność" ${ }^{\text {.3 }}$ Bo kontakty, które powstały we Wrocławiu... Na początku na Placu Czerwonym ${ }^{44}$ się odbywały takie zebrania. No [nawiązywaliśmy] kontakty z zakładami, z różnymi instytucjami, w których już były związki zawodowe i były silniejsze niż u nas. Bo nasz to nie był taki typowy zakład produkcyjny typu Fadroma ${ }^{45}$, Hutmen ${ }^{46}$, Elwro ${ }^{47}$, [czy jak] MPK - bo tam

Lublin-Siedlce 2011, s. 783-80o; M. Korejwo, Próba systematyzacji podstawowych ogniw PZPR na podstawie olsztyńskiej wojewódzkiej organizacji partyjnej, „Komunizm: system - ludzie - dokumentacja”, nr 1 (2012), s. 101-110.

43 Międzyzakładowe Komitety Założycielskie (MKZ) z całego kraju już 17 września w Gdańsku powołały Niezależny Samorządny Związek Zawodowy „Solidarność, który formalnie zostaje zarejestrowany 10 XI 1980 r.; L. Ziątkowski, Na drodze do wolności..., s. 46-48; W. Formański, Meandry legalizacji NSZZ „Solidarność” (Autentyczna relacja z wydarzeń wokót legalizacji w listopadzie 1980 roku), Warszawa 1996; T. Kozłowski, Droga do rejestracji, „Biuletyn Instytutu Pamięci Narodowej”, nr 9-10 (2010), s. 98-103.

44 Obecnie Plac Solidarności. Wspomniane zebrania odbywały się w dawnym budynku fabryki tytoniu na Placu Solidarności nr 1/3/5.

45 Zakłady produkcji maszyn budowlanych, mieszczące się przy ul. Grabiszyńskiej we Wrocławiu.

46 Przedsiębiorstwo z branży hutniczej (głównie przetwórstwo miedzi), z siedzibą przy ul. Grabiszyńskiej we Wrocławiu.

47 Wrocławskie Zakłady Elektroniczne „Elwro”, produkujące komputery „Odra”, zlokalizowane w sąsiedztwie ul. Grabiszyńskiej, przy ul. Ostrowskiego zo. 
była taka załoga bardzo zróżnicowana i bardzo, że tak powiem, naciskająca

na powstanie związków. U nas aż takiego mocnego nie było nacisku, ale myśmy tak odgórnie próbowali to zrobić i zaczęliśmy organizować związek. Zorganizowaliśmy [go] oczywiście w miarę szybko, przygotowaliśmy statuty zakładowe itd. [Mieliśmy] mnóstwo pracy takiej od początku, bo pojęcia nie mieliśmy, jak się organizuje takie związki zawodowe. Ale na bieżąco była prasa czy jakieś tam z drugiego obiegu informacje, książki, które dostawaliśmy z różnych zakładów. Później powstał związek zawodowy, który miał organizację, no i poprzez wybory do władz związku zostałem przewodniczącym oddziałowej organizacji związkowej „Solidarność”, no i jednym z wiceprzewodniczących Zakładowej Organizacji Związkowej „Solidarność”. No i tak działaliśmy ${ }^{48}$ przez praktycznie od września [1980] do grudnia $1981 \mathrm{r}$.

[...] W tym czasie w ogóle nie myślałem o czymś takim [jak konsekwencje w postaci aresztowania czy prześladowania], gdyż byłem przekonany, że ten związek na pewno wytrwa i zmieni kraj. Byłem do końca przekonany, do ostatniego dnia ${ }^{49}$, że nie można takiej organizacji zniszczyć, nie można! Nie przychodziło mi do głowy, żeby się bać - w tym czasie absolutnie się nie bałem.

\section{Wprowadzenie stanu wojennego}

[...] Jeszcze w sobotę [12 grudnia 1981 r.] pracowałem, mimo że to była chyba nawet jakaś wolna sobota, bo to wtedy myśmy walczyli o te wolne soboty $^{50}$, więc to chyba była wolna sobota. Pojechałem jeszcze w delegację do Brzegu Dolnego, bo tam prowadziłem inwestycję - mocno byłem w to zaangażowany, dlatego pojechałem. Coś tam jeszcze jakiś wykonawca roboty robił. Wróciłem, nawet poszedłem jeszcze w sobotę do zakładu, gdzie tam przygotowywałem jeszcze jakieś dokumenty związane z działalnością „Solidarności”. Nawiasem mówiąc, sytuacja była bardzo trudna, bo parę

48 O charakterze tej działalności zob. niżej.

49 Chodzi zapewne o moment wprowadzenia stanu wojennego i delegalizację „Solidarności”.

50 Jak już wspomniano, był to jeden z postulatów sierpniowych, którego realizację od stycznia $1981 \mathrm{r}$. władze zapowiedziały w porozumieniach podpisanych ze strajkującymi, a którego nie zrealizowały, co doprowadziło do ogólnopolskich strajków i kompromisu w postaci trzech wolnych sobót w roku; T. Chinciński, Jutro wolna sobota, „Biuletyn Instytutu Pamięci Narodowej”, nr 10 (33) (2003), s. 53-56. 

był, był m.in. Karol Modzelewski ${ }^{53}$, i mówili, że rzeczywiście sytuacja się dość mocno zaostrza, ale ja sądziłem, że mimo wszystko to jakoś się dogadają władze partyjne z władzami związkowymi i że nie dojdzie do stanu wojennego, bo będą się bali strajku generalnego, no ale okazało się inaczej. Wróciłem do domu wieczorem, no ale zawsze o godzinie 6 rano wstawałem i słuchałem Radia Wolna Europa ${ }^{54}$, słuchałem radia $\mathrm{BBC}^{55}$ i inne. Właśnie

51 Wrocławskie zakłady produkcyjne z branży elektromechanicznej przy ul. Fabrycznej - jeden z ówczesnych „bastionów” Solidarności w mieście; zob.: Ł. Sołtysik, op. cit., s. $18-19$.

52 Władysław Frasyniuk (ur. 1954 r.) - latach 1976-1978 kierowca we wrocławskich przedsiębiorstwach PKS i Transbud, od 1978 r. w MPK we Wrocławiu. Uczestnik strajku w Zajezdni nr VII i rzecznik MKS w sierpniu 1980 r., od września rzecznik MKZ. W 1981 r. delegat na I Wojewódzki Zjazd Delegatów NSZZ „Solidarność” (WZD), a następnie na I Krajowy Zjazd Delegatów NSZZ „Solidarność” (KZD), przewodniczący Zarządu Regionu Dolny Śląsk oraz członek prezydium Komisji Krajowej NSZZ „Solidarność” (KK); http://www.encysol.pl/wiki/W\%C5\%82adys\%C5\%82aw_ Frasyniuk (dostęp: 15 X 2018 r.).

53 Karol Modzelewski (1937-2019) - w latach 1972-1983 pracownik naukowy w Instytucie Historii Kultury Materialnej Polskiej Akademii Nauk (PAN) we Wrocławiu, wcześniej wielokrotnie aresztowany za krytyczną postawę wobec władz PRL. Od września roku 1980 wiceprzewodniczący Komitetu Założycielskiego we wrocławskich oddziałach PAN; 17 września, jako delegat dolnośląskiego MKZ, uczestniczył w Gdańsku w powołaniu NSZZ „Solidarność". Od listopada 1980 r. rzecznik Krajowej Komisji Porozumiewawczej (KKP), po ustąpieniu w kwietniu 1981 r. ze stanowiska (m.in. na znak protestu wobec stylu uprawiania przywództwa przez Lecha Wałęsę) był delegatem na I WZD, a następnie na I KZD, a także członkiem dolnośląskiego Zarządu Regionu oraz członkiem prezydium KK; http://www.encysol.pl/wiki/ Karol_Modzelewski (dostęp: 15 X 2018 r.).

54 Amerykańska rządowa rozgłośnia radiowa, nadająca od 1950 r. dla obywateli państw komunistycznych, w których ograniczano wolność słowa; zob. A.R. Johnson, Radio Free Europe and Radio Liberty. The CIA years and beyond, Washington 2015; A. Puddington, Broadcasting Freedom. The Cold War Triumph of Radio Free Europe and Radio Liberty, Lexington 2000; G. Adamczewski, Radio Wolna Europa w okresach politycznych przełomów, Wrocław 2011; J. Hajdasz, Szczekaczka, czyli Rozgtośnia Polska Radia Wolna Europa, Poznań 20o6; zob. ponadto archiwum Rozgłośni Polskiej Radia Wolna Europa: Radia Wolności: https://www.polskieradio. pl/68,Radia-Wolnosci (dostęp: 29 I 2019 r.).

55 BBC (British Broadcasting Corporation) - brytyjski nadawca publiczny, nadający w czasie zimnej wojny (podobnie jak Radio Wolna Europa) programy radiowe skierowane do mieszkańców tzw. bloku wschodniego; zob. więcej: K. Pszenicki, Tu mówi 
w tym dniu [13 grudnia], 6 rano w niedzielę, kiedy ludzie często spali, [więc] dowiedzieli się dość późno, to ja o godzinie 6 włączyłem radio i dowiedziałem, że jest stan wojenny. Wyjrzałem zresztą przez okno i już było widać na Sołtysowicach ${ }^{56}$ pełno wojska, milicji, bo to w pobliżu były jednost$\mathrm{ki}^{57}$, więc tędy jeździły samochody milicyjne i wojskowe. Widać, że coś się dzieje nie takiego, więc próbowałem zejść na dół ${ }^{58}$, dodzwonić się [do kogoś], bo telefonu wtedy w domu nie miałem, zresztą mało kto miał, żeby się czegoś więcej dowiedzieć. Telefony oczywiście już nie działały ${ }^{59}$. Obudziłem żonę $e^{60}$. Żona do kościoła poszła, a ja chyba próbowałem się gdzieś tam z kimś skontaktować. Poszedłem chyba wtedy pod związek zawodowy zobaczyć, co się tam dzieje, a tam już też oczywiście pełno stało $\mathrm{ZOMO}^{61}$, milicji i wynosili niektóre rzeczy ${ }^{62}$. Z tego, co tak pamiętam, no to trochę ludzi przyszło zdezorientowanych. Także niedziela nerwowa - czekaliśmy, żeby się po prostu z kimś skontaktować, bo to nie tak jak dzisiaj, że ludzie mogą do kogoś zadzwonić, trzeba było pojechać. Każdy wychodził i szukał swoich kontaktów - no zdenerwowanie i oczekiwanie na pierwszy dzień pracy, gdzie wiedzieliśmy, że się z kimś tam spotkamy. Tak praktycznie w tą pierwszą niedzielę spotkałem ludzi, którzy... ale z tych swoich znajomych bardzo mało, bo każdy wyszedł i gdzieś

Londyn. Historia sekcji Polskiej BBC, Warszawa 2009; A. Webb, London calling. Britain, the BBC World Service, and the Cold War, London 2015.

56 Osiedle we Wrocławiu w dzielnicy Psie Pole.

57 Chodzi o kompleks koszar wojskowych na Karłowicach we Wrocławiu, gdzie stacjonowały również wojska radzieckie.

58 Świadek mógł mieć na myśli zejście do znajdującego się w pobliżu mieszkania automatu telefonicznego lub do któregoś z sąsiadów.

59 Z chwilą wprowadzenia stanu wojennego w ramach operacji „Azalia” została całkowicie odcięta łączność telefoniczna na terenie całego kraju, którą częściowo przywrócono dopiero 10 I 1982 r.; A. Paczkowski, Stan wojenny i „powojenny”: od grudnia 1981 do stycznia 1989, [w:] Polski wiek XX, t. 4, red. K. Persak, P. Machcewicz, Warszawa 2011, s. 209 i nn.; Ł. Kamiński, P. Piotrowski, Dolny Śląsk $i$ Śląsk Opolski, [w:] Stan wojenny w Polsce 1981-1983, red. A. Dudek, Warszawa 2003, s. 27.

60 Krystyna Adamczyk (ur. 1950 r.) - ówcześnie pracownik administracyjny w Polskich Kolejach Państwowych.

${ }^{61}$ Zmotoryzowane Odwody Milicji Obywatelskiej, utworzone po zamieszkach w Poznaniu w czerwcu 1956 r. w celu „likwidacji zbiorowych naruszeń porządku publicznego"; więcej zob.: J. Eisler, op. cit., s. 28 i nn.

${ }^{62}$ W ramach operacji "Jodła” m.in. zajmowano lokale należące do "Solidarności”, A. Paczkowski, Stan wojenny..., s. 209; W. Suleja, op. cit., s. 135-154. 
tam czegoś szukał - kontaktu. Także mało znajomych ludzi spotkałem. Dopiero zaczęło się to wszystko w poniedziałek, gdzie ukazały się już gazety reżimowe ${ }^{63}$ itd. No i spotkaliśmy się w zakładzie pracy, spotkaliśmy się u kolegi, w takim małym pomieszczeniu, na zapleczu Rynku, on tam miał i prowadził zakład usługowy. No i tam u niego się spotkaliśmy i zaczęliśmy się zastanawiać, jak to dalej działać. Cały praktycznie sztab [był tam], postanowiliśmy powołać taką tajną komisję zakładową - tak jej zresztą wtedy nie nazywaliśmy, ale nieoficjalnie tak trzeba było to zrobić. Oczywiście do [siedziby] związku już nie można było wejść, czyli do naszego pokoju „Solidarności”, więc to, co tam zostało, jakieś dokumenty, jakieś nawet nasze prywatne rzeczy, to nie można było z tego korzystać, no i zaczęliśmy się organizować - jakieś różne ulotki, to, tamto. Dostawaliśmy [je] najpierw. Później zorganizowaliśmy w zakładzie pracy, była powielarnia - dziewczyny, które tam pracowały, mimo że to było bardzo mocno strzeżone - każdy papier, który dostawały dziewczyny do wydrukowania itd., musiał przechodzić najpierw przez ręce przynajmniej 4-5 osób, które decydowały. Aby powielić jakikolwiek dokument, to trzeba było dostać przynajmniej 5 pieczątek - od dyrektora poprzez zakładowego jakiegoś tam kapusia wojskowego itd. Dopiero wtedy można było powielić, oczywiście w 1-2 egzemplarzach. Ale ludzie jakoś tam dawali sobie radę - zorganizowali trochę papieru, no i część rzeczy udało się jednak powielić - dziewczyny ryzykowały bardzo dużo, prawda, więc okazało się później, nawet nie o wszystkim wiedziałem, że drukowały nawet nieraz po kilkaset sztuk różnej niezależnej prasy czy ulotek. Robiły to tak, że nawet nie zawsze myśmy wiedzieli, choć byliśmy w bardzo bliskim kontakcie [śmiech]. Tak to mniej więcej to wyglądało przez pierwsze dni. Przy okazji oczywiście zaczęliśmy zbierać fundusze dla internowanych ${ }^{64}$ - papierosy, tam jakieś kartki na papierosy czy pieniądze.

${ }^{63}$ Wraz z wprowadzeniem stanu wojennego zawieszono wydawanie większości ówczesnej prasy, a zakaz ten nie objął jedynie lokalnych dzienników partyjnych i dwóch pism ogólnopolskich: „Trybuny Ludu” oraz „Żołnierza Wolności”; M.O. Sikkora, Prasa gdańska w stanie wojennym (1981-1983). Przegląd problemowy, „Acta Cassubiana”, nr 12 (2010), s. 123, 135; A. Ruciński, Instytucje medialne w okresie stanu wojennego, „Przegląd Prawniczy, Ekonomiczny i Społeczny”, nr 2 (2013), s. 56-70.

64 W ramach operacji „Jodła” pierwszej doby internowano 3,4 tysiąca osób, do 22 grudnia blisko 5,2 tysiąca, zaś w trakcie trwania całego stanu wojennego ponad 10 tysięcy; A. Paczkowski, Stan wojenny..., s. 209-211; T. Kozłowski, J. Olaszek, Internowani w stanie wojennym. Dane statystyczne, „Pamięć i Sprawiedliwość”, nr 9/2 (2010), 
No bo wiadomo było, że mnóstwo ludzi było internowanych, natomiast nam się udało jakoś tak uniknąć, bo myśmy specjalnie nie zadzierali z naszą [zakładową] organizacją partyjną. Dowiedziałem się dopiero po paru latach, znaczy się już dobrze w latach 9o., że o tym, że nas nie aresztowali w tych pierwszych dniach, to decydowała zakładowa organizacja partyjna ${ }^{65}$ - oni decydowali, no i oczywiście dyrektor, który rzeczywiście okazało się, że dyrektor mojego zakładu pracy nie był aż taki zły, na jakiego wcześniej wyglądał. To był dawny akowiec ${ }^{66}$ i on rzeczywiście... Nawiasem mówiąc nazywał się Czuma, to jego kuzyn, który był aresztowany, był wcześniej organizatorem w Warszawie na manifestacjach niezależnych ${ }^{67}$, to był jego kuzyn. Znaczy się jego brata chyba syn. No i ten Czuma po prostu zadecydował oraz organizacja partyjna, że nas nie aresztowali w stanie wojennym. Bo byliśmy na tej liście, no i troszeczkę pewnie wybierali, bo nie mieli tylu miejsc i stąd tych działaczy takich może mniej radykalnych jak u nas - u nas praktycznie żadna osoba w pierwszych dniach nie została aresztowana. Tak to mniej więcej pierwsze dni wyglądały.

[Po wprowadzeniu stanu wojennego] pozmieniali u nas w zakładzie pracy dyrektorów - część sama odeszła - przyszli nowi i wtedy to się wszystko zaczęło. Wpierw jakieś tam ostrzeżenia w zakładzie pracy, bo wiedzieli, że coś się dzieje, więc przeszukiwania biurka, to tamto - to było standardowe, czy czegoś tam nie ma. No i w którymś momencie zaczęliśmy więc organizować tak prawie że oficjalnie niektóre rzeczy - rozrzucaliśmy ulotki. To był sprzeciw, kiedy próbowano zalegalizować reżimowe związki zawodowe ${ }^{68}$. No to wtedy ja prawie oficjalnie wystąpiłem o zwrot naszych pieniędzy, które były zablokowane na koncie ${ }^{69}$ - naszych, czyli związkowych pieniędzy.

S. 507-510; W. Polak, Internowania w nocy z 12 na 13 grudnia 1981, „Biuletyn Instytutu Pamięci Narodowej”, nr 11-12 (2011), s. 91-98.

65 Zob. przypis 41.

66 W czasie II wojny światowej żołnierz Armii Krajowej.

67 Była to najprawdopodobniej przypadkowa zbieżność nazwisk.

68 Chodzi tu o utworzone w 1984 r. Ogólnopolskie Porozumienie Związków Zawodowych (OPZZ), które do końca istnienia PZPR było z nią blisko związane; zob. Ogólnopolskie Porozumienie Związków Zawodowych: https://encyklopedia.pwn.pl/ haslo/Ogolnopolskie-Porozumienie-Zwiazkow-Zawodowych;3950296.html (dostęp: 29 I 2019 r.).

69 Chodziło zapewne o pieniądze ze składek członkowskich ulokowane najprawdopodobniej w Narodowym Banku Polskim, które w wyniku wprowadzenia stanu wojennego zostały zablokowane; A. Paczkowski, Stan wojenny..., s. 211. 
Wystąpiłem o zwrot tych pieniędzy i chodziłem do wszystkich członków związku, żeby się podpisywali - ludzi część się bała, część tam podpisywała. No ale jako organizatorowi mi zarzucili, że ja wykorzystywałem maszynę służbową do napisania takiego krótkiego pisma: „Proszę o zwrot pieniędzy związkowych". Od tego się praktycznie wszystko bardzo mocno zaczęło, bo natychmiast przyjechała milicja, łącznie z panem porucznikiem Bełcikiem $^{70}$, który nie wiem, czy pracuje teraz $\mathrm{w}$ policji - pewnie został teraz dobrym policjantem w dzisiejszych czasach [śmiech]. Przyszli [milicjanci], próbowali mnie... Nie, pierwsze powiedzieli żebym się do nich zgłosił - ja powiedziałem, że nie przyjdę, więc obstawili cały zakład - przyjechały dwa samochody. Nawiasem mówiąc, gdybym chciał, to mógłbym uciec przez dach, bo na tyle znałem już ten zakład, ale oczywiście nie uciekałem - mówię, co będę się chował przed nimi. Więc wyprowadzili mnie, kurczę, a ludzie bili brawo [śmiech], ale nie im, tylko mi, że wyszedłem z godnością $\mathrm{z}$ tego zakładu pracy. No i tak się zaczęło $-\operatorname{tam}^{71}$ przetrzymywali mnie po kilka razy. Ale to dlatego, że przyszedł nowy dyrektor - znaczy się ten naczelny to został, czyli Czuma był nadal - ale przyszedł nowy dyrektor do spraw pracowniczych i on to organizował te takie nagonki na tych ludzi. No i była okazja, bo natychmiast trzeba było zreorganizować przedsiębiorstwo i zostałem praktycznie wyrzucony z pracy - nie miałem praktycznie możliwości zatrudnienia w WPHW, mimo iż prowadziłem inwestycję, którą trzeba było skończyć - absolutnie nikt się tym nie przejmował i przy reorganizacji zostałem jakimś tam, no z łaski jednego z dyrektorów jednego z oddziałów, które powstały na bazie tej firmy, zostałem jakimś tam rejonistą sklepowym. Zupełnie na tym się nie znałem, ja prowadziłem inwestycje i miałem techniczne wykształcenie, a oni kazali mi się zajmować sprawami takimi związanymi z wyposażeniem sklepu, z tym czym handluje się, ale to mówię, i tak z łaski jednego z dyrektorów, który, biorąc odpowiedzialność za mnie, chciał mi pomóc i rzeczywiście pomógł. Tak że przez pewien czas pracowałem więc jako taki rejonista, gdzie też praktycznie żadnej roboty

70 Prawdopodobnie chodzi o Jerzego Bełcika, por.: https://katalog.bip.ipn.gov.pl/informacje/17955 (dostęp: 28 I 2019 r.).

71 Mogło chodzić o komendę milicji na Karłowicach, o której świadek w dalszej części relacji wspomina, iż często był na nią wzywany czy doprowadzany lub o więzienie przy ul. Kleczkowskiej, które było miejscem internowania wrocławskich opozycjonistów w czasach PRL; K. Szwagrzyk, Naczelnicy więzienia przy ul. Kleczkowskiej we Wrocławiu 1945-1955, „Biuletyn Instytutu Pamięci Narodowej”, nr 6 (2002), s. 55. 
nie było - zresztą jak to za komuny, bardziej się udawało, niż się robiło, bo

to była sprawa taka, że te stanowiska były zupełnie niepotrzebne. Ale miałem bardzo dobrze, bo miałem przynajmniej widok - pracowałem na ulicy Zelwerowicza - i widziałem, jak milicja przygotowuje się na każdą manifestację, bo tam były [obok] warsztaty samochodowe [śmiech]. Widziałem, kiedy wyjeżdżają, jak wyjeżdżają - mogłem parę informacji na ten temat przekazać nawet dalej do związków zawodowych czy do tej organizacji naszej, takiej niezależnej. Tak mniej więcej [to] wyglądało.

\section{Wydawnictwo podziemne}

[...] W momencie, kiedy mnie zwolnili z tego zakładu [WPHW], więc w tym nowym bardzo mało ludzi znałem, bo to powstała firma Arpis ${ }^{72}$, to tych ludzi nie znałem. Ale kontakty po prostu nawiązałem z innymi firmami i powstała taka niezależna grupa, i zaczęliśmy zajmować się wydawnictwami. Powstało niezależne wydawnictwo - Niezależne Robotnicze Wydawnictwo „Feniks” - gdzie zaczęliśmy drukować książki, albumy - między innymi ja fotografowałem manifestacje. Zorganizowaliśmy to wydawnictwo ${ }^{73}$ i wydawaliśmy książki, m.in. [wiersze] [Bogusława] Kierca ${ }^{74}$, Anty-Rakowski². Kilkanaście książek udało się nam wydrukować na takich prostych maszynach typu skład

72 Chodzi o Przedsiębiorstwo Handlu Artykułami Papierniczymi i Sportowymi „Arpis” mieszczące się przy ul. Zelwerowicza 16.

73 Według Tadeusza Piątka, oprócz niego oraz Jerzego Adamczyka w zorganizowanie wydawnictwa zaangażowali się również: Antoni Cydzik, Wiesław Leśniański, Stanisław Łuszcz, Mieczysław Perlak, Zbigniew Dudek, Marian Cieślikowski, Janusz Słodziński oraz Jan Beluch; zob.: http://www.sw.org.pl/feniks.html (dostęp: 23 IX 2018 r.).

74 Bogusław Kierc (ur. 1943 r.) - poeta, aktor, reżyser i wykładowca akademicki, odznaczony medalem „Zasłużony Kulturze Gloria Artis”; zob. więcej: https://culture.pl/pl/ tworca/boguslaw-kierc.

75 Chodzi o esej Anty-Rakowski, czyli o tym co wygwizdali wicepremierowi robotnicy, którego autorem był pracownik Uniwersytetu im. Adama Mickiewicza w Poznaniu Leszek Nowak; zob.: http://www.wbc.poznan.pl/dlibra/doccontent?id=399651 (dostęp: 23 IX 2018 r.); por.: okładka i przykładowe strony egzemplarza wydanego przez „Feniks”: http://www.sw.org.pl/images/feniks1a.jpg (dostęp: 23 IX 2018 r.) oraz: http://www.sw.org.pl/images/feniksıb.jpg (dostęp: 23 IX 2018 r.). Esej ukazał się ponownie w zbiorze wydanym przez IPN, zob.: L. Nowak, Polska droga od socjalizmu. Pisma polityczne 1980-1989, [w:] Studia i Materiaty Poznańskiego IPN, t. XVII, red. K. Brzechczyn, Poznań 2011, s. 428-452. 
drukarski $^{76}$. Wyniesionych nawiasem mówiąc przez Roberta ${ }^{77} \mathrm{z}$ drukarni wojskowej - pewnie o tym niewielu wie, ale nawet się okazało, że pracował w drukarni wojskowej, udało mu się wyciągnąć stamtąd czcionki, na Politechnice [Wrocławskiej] wykonaliśmy specjalne do tego jakieś tam obręcze, które się wkładało pod poszczególne czcionki i tworzyliśmy po prostu nowe techniki drukarskie i do tej pory te książki istnieją - kilkanaście książek ${ }^{78}$, łącznie z pięknymi nawet grafikami, które kolega przygotowywa ${ }^{79}$. Nawet w ostatnich czasach osobiście sprezentowałem panu Bogusławowi Kiercowi - to jest nasz aktor wrocławski, poeta i jednocześnie reżyser, który dał nam prawa autorskie do wydrukowania tych książek [i] nie chciał z tego tytułu jakichś tantiem. W ubiegłym roku na spotkaniu takim teatralnym dałem mu chyba dwie książki z tego tytułu, że pozwolił nam to drukować - chociaż wcześniej też dostał [egzemplarze], jako taki opozycjonista. Nawiasem mówiąc, gdy zginął ten Kazimierz Michalczyk $^{80}$, to nazwaliśmy ulicę imieniem Kazimierza Michalczyka - ulica Kazimierza Michalczyka teraz jest gdzieś w innym miejscu, nie wiem którym ${ }^{81}$. Natomiast wtedy to była chyba ulica Rogowska - tam żeśmy to drukowali ${ }^{82}$. No i przez przypadek namierzyli kolegę ${ }^{83}$, wpadli, milicja wpadła i zabrała nam resztę książek, które zdążyliśmy wydrukować, zabrała nam wszystkie maszyny drukarskie, wszystkie urządzenia,

76 Chodzi o maszyny skonstruowane przez Tadeusza Piątka, nazwane „Warchoł” i „Warchoł 2”; zob.: http://www.sw.org.pl/feniks.html (dostęp: 23 IX 2018 r.).

77 Chodzi o Roberta Sierpowicza (ur. 1964 r.) - siostrzeńca Jerzego Adamczyka, który do dziś zajmuje się drukarstwem.

78 Lista wydrukowanych książek i czasopism, zob.: http://www.sw.org.pl/feniks.html (dostęp: 23 IX 2018 r.); por.: M. Wanke-Jakubowska, M. Wanke-Jerie, op. cit., s. 9-10; http://www.encysol.pl/wiki/Jerzy_Adamczyk (dostęp: 23 IX 2018 r.).

79 Według Tadeusza Piątka grafiki przygotowywał Stanisław Ryczek; http://www. sw.org.pl/feniks.html (dostęp: 23 IX 2018 r.).

80 Kazimierz Michalczyk (1955-1982) - pracownik zakładów „Elwro” we Wrocławiu, postrzelony przypadkowo 31 VIII 1982 r. podczas rozpędzania przez władze demonstracji z okazji drugiej rocznicy podpisania porozumień sierpniowych, zmarł w szpitalu dwa dni później, a jego pogrzeb zamienił się w wielką manifestację przeciw władzy; J. Kordas, Wydarzenia 31 sierpnia 1982 r. na Dolnym Ślasku Geneza, przebieg, skutki, Wrocław 2010, s. 88 i nn.; W. Suleja, op. cit., s. 153-154.

81 Taką nazwę nosi boczna ulica ul. Długiej we Wrocławiu.

82 Drukowano przy ul. Rogowskiej 172/18, w mieszkaniu Tadeusza Piątka; zob.: http:// www.sw.org.pl/feniks.html (dostęp: 23 IX 2018 r.).

83 Chodzi o Tadeusza Piątka; zob. http://www.sw.org.pl/feniks.html (dostęp: 23 IX 2018 r.). 
no i Urban wystąpił, bo to był przecież 1 Maja ${ }^{84}$, wystąpił w telewizji, że jeszcze jedną wielką drukarnię we Wrocławiu udało się zlikwidować. A to była naprawdę niewielka drukarenka, gdzie pracowało nas tam 5 czy 6 osób. A satysfakcję mieli jednak ogromną, cała telewizja wrocławska podała, później oczywiście Urban, cała ogólnopolska, że wielką drukarnię zlikwidowali. No udało się nam uniknąć aresztowania, bo syn tego kolegi, jak jego zamknęli, to ten syn ostrzegł nas i także między sobą udało się nam jakoś powiadomić, że jest wpadka i tam nikt się więcej nie zjawił. Natomiast kolegę zmusili, że musiał wystąpić w telewizji i coś na [ten] temat powiedzieć, jak to wygląda. No więc on... Chcieli właściwie, żeby się bił w piersi i powiedział, że nie warto walczyć, no bo to się tak kończy. No więc on zmuszony był, bo przetrzymywali go przez ileś dni, no i wystąpił w telewizji i na tej zasadzie powiedział, że no jak zaczynał tą pracę, to ważył $80 \mathrm{~kg}$, a teraz waży 70 i jest umęczony tą pracą, no i tak się to skończyło. Co prawda kolegium zapłacił, ale po paru dniach, czy parunastu, go wypuścili. To już były praktycznie lata... koniec lat 8o., rok osiemdziesiąty chyba siódmy, tak [19]87 r., no więc przez tych przynajmniej 5 lat ta nasza drukarnia działała. Wydaliśmy trochę, tak jak mówiłem, albumów, trochę znaczków, trochę książek, trochę różnych jakichś tam wydawnictw okolicznościowych, świątecznych - $\operatorname{kartek}^{85}$. No i to się zachowało, także myślę, że pamiątki są, tym bardziej, że wysyłaliśmy te książki nasze, jak się ukazywały, nawet do Ossolineum ${ }^{86}$, żeby w Bibliotece Narodowej zostały. Czy one są, to trudno powiedzieć, ale w każdym razie u nas i u części ludzi się zachowało.

\section{Działalność w stanie wojennym - „i śmieszno, i straszno”}

Na co dzień [była] oczywiście taka normalna działalność związkowa, typu pomoc ludziom internowanym, roznoszenie ulotek - to takie działanie, że

84 Zob. szerzej na temat regularnych, cotygodniowych konferencji prasowych organizowanych przez Jerzego Urbana: T. Krupski, Władza komunikuje się ze społeczeństwem. Jerzy Urban i jego konferencje prasowe dla dziennikarzy zagranicznych, [w:] Opozycja i opór społeczny w Polsce po 1956 roku, t. 2, red. T. Kozłowski, J. Olaszek, Warszawa 2014, s. 234-280.

85 Zob. http://www.sw.org.pl/images/feniks-karta1.jpg (dostęp: 23 IX 2018 r.); http:// www.sw.org.pl/images/feniks-karta2.jpg (dostęp: 23 IX 2018 r.); http://www.sw.org. pl/images/feniks-karta3.jpg (dostęp: 23 IX 2018 r.).

86 Chodzi o Zakład Narodowy im. Ossolińskich, instytucję naukową i kulturalną, gromadzącą zbiory biblioteczne we Wrocławiu. 
tak powiem, standardowe było. Co tam jeszcze? Oczywiście wywieszanie różnych haseł, typu „Solidarność zwycięży”, czy pisanie na murach... To było praktycznie przed każdą rocznicą typu 1 Maja czy 3 Maja czy jakieś inne święto, czy 31 sierpnia $^{87}$. Chociaż mnie często w tych czasach zatrzymywano. Zwykle to było, [że] zatrzymywali 2-3 dni wcześniej albo przynajmniej wzywali na rozmowę i ostrzegali, że jeżeli coś będę robił, to po prostu mnie aresztują [śmiech]. Tak że miałem parę razy po prostu zatrzymania, wręcz były to takie demonstracyjne - wyciągali mnie z domu czy z pracy. Takie tam były sprawy, które nie są może warte, aby o nich mocno wspominać. W którymś momencie się mocno wkurzyłem - bo to było, [że] wróciłem z wczasów, gdzie rzeczywiście [było to] przed 31 sierpnia i wzięli mnie na komendę na dawnym placu Gottwalda, teraz to plac Piłsudskiego chyba się nazywa, na komendzie na Karłowicach. Zaczęli mnie tam dość mocno straszyć, że coś się tutaj dzieje wokół miejsca, gdzie zamieszkuję - mieszkałem [wtedy] na Sołtysowicach. No to ja mówię [do siebie] nie, ja też wam zrobię taki kawał. Takie oczyszczalnie ścieków tam były w cukrowni ${ }^{88}$, więc ja w tym momencie wieczorem... - oczywiście bardzo to wszystko wysokie, wysoki budynek - wszedłem tam na górę, wyrysowałem hasła Solidarności Walczącej i jakieś tam jeszcze inne, wywiesiłem kilka flag, postawiłem oprócz tego dwie cegły, włożyłem je w jakiś karton i napisałem „Uwaga bomba!". Wystawiłem jakieś tam dwa przewodziki [z tego karto$\mathrm{nu}$ ] - to było wieczorem. Rano oczywiście flaga i jeszcze inne [tam były] - to było w pobliżu przejazdu pociągów, które jeździły trasą na Warszawę. Raniutko, gdy tylko mgła opadła - to było 31 sierpnia, to była oczywiście rocznica powstania "Solidarności” - widzę tam pełno milicji, wojska, a ja $\mathrm{z}$ okna oglądałem to z dużą satysfakcją. Wydawało im się, że rzeczywiście wielką bombę mają, a tam były tylko dwie cegły. Na pewno dziś, gdyby policja to widziała, to powiedzieliby, że rzeczywiście „bombardier” [śmiech], ale wtedy to były inne czasy i inaczej na to trzeba było spoglądać. Widzę, że się wkurzyli... Najbardziej to mnie denerwowało, jak oni te flagi polskie zrzucali, bo tam były i flagi polskie, i ze znakiem Solidarności Walczącej, i oni

87 Chodzi o rocznice podpisania porozumień sierpniowych; zob. Porozumienia Sierpniowe - poczatek przemian...

88 Chodzi o nieistniejącą już cukrownię przy al. Poprzecznej, na jej terenie w czasie II wojny światowej funkcjonował niemiecki obóz pracy przymusowej Burgweide; zob.: https://kochamwroclaw.pl/burgweide-najwiekszy-oboz-pracy-przymusowej-w-breslau/ (dostęp: 23 IX 2018 r.). 
to zrzucali z góry z dużą satysfakcją. Takie to wtedy były sytuacje, bardzo często różne podobne, o których tam nie warto nawet mówić.

[...] Łapali ludzi - to normalne, [że] przychodziło się do katedry ${ }^{89}$, a praktycznie każdego 13. były takie msze za Ojczyznę, najczęściej w katedrze. W którymś momencie, oczywiście wychodząc z katedry, próbowali mnie zatrzymać. Nie powiem, że ja byłem taki pokorny, ale podchodzi do mnie jakiś tam ubek ${ }^{90}$, oczywiście nie milicjant, i coś tam mi mówi, żebym przeszedł na drugą stronę ulicy. Ja mówię dobrze, ale z tej drugiej strony ulicy, bo taka była sytuacja, że z tej drugiej strony ulicy - tam jak się z katedry wychodziło - kazali przejść na tą stronę. I tak nas próbowali w tą i w tą stronę ganiać. Więc ja tłumaczę mu - no to wykręcili mi ręce, wrzucili do „suki”" . Oczywiście było już tam kilka osób i m.in. była tam kobieta, która autentycznie przyszła się pomodlić do katedry. Bo ja przyszedłem w określonym celu, a ta kobieta przyszła tylko po to, aby się pomodlić, i nie wiedziała, dlaczego ją zatrzymują. I, kurczę, okazało się, że po prostu wepchnęli ją tam, a nie dość, że w tej „suce” były dwa miejsca przedzielone, to jeszcze jakby ktoś specjalnie nakładł blach żelaznych - nie sądzę, żeby one tam były, bo ktoś je od tak przewoził - i wpychali tych ludzi na te blachy, to były takie blachy ryflowane, jakby [ktoś] powycinał rzeczy, żeby się ludzie mogli łatwo przewracać. I tak rzeczywiście tą kobietę wepchali tam, m.in. [też] mnie i jeszcze kilkanaście osób, i zawieźli nas na komendę na ul. Grunwaldzką. No i tam, kurczę, oczywiście „ścieżka zdrowia”92, czyli taka, jak w [19]76 w Radomiu ${ }^{93}$. Trzeba było przechodzić obok milicji i wystarczyło, że się nie spodobałeś, to od razu dostawałeś w głowę pałą. A że myśmy dostawali, to tam, mówię, pół biedy, bo to byli ludzie tacy [jak ja],

89 Chodzi o Archikatedrę św. Jana Chrzciciela we Wrocławiu.

9 Ubek, esbek - kolokwialnie o funkcjonariuszach Urzędu/Służby Bezpieczeństwa.

91 Było to obraźliwe określenie milicyjnych furgonów marki Nysa, z której wychodzą „psy”, czyli funkcjonariusze.

92 Była to „forma znęcania się nad uczestnikami strajków lub demonstracji ulicznych, polegająca na zmuszaniu osoby zatrzymanej do przejścia przez szpaler funkcjonariuszy MO bijących na oślep pałkami milicyjnymi”; Z. Zblewski, Czym byty milicyjne „ścieżki zdrowia”? Przypominamy relację z pierwszej ręki, https://twojahistoria.pl/2018/o2/o3/czym-byly-milicyjne-sciezki-zdrowia-przypominamy-relacje-z-pierwszej-reki/\#2 (dostęp: 29 I 2019 r.).

93 Chodzi o protesty robotnicze do których doszło 25 VI 1976 r. w Płocku, Radomiu i Ursusie w odpowiedzi na drastyczną podwyżkę cen podstawowych produktów żywnościowych; zob.: P. Sasanka, op. cit. 
a ja wtedy miałem trzydzieści parę lat, ale ta kobieta miała naprawdę siedemdziesiąt parę, przyszła się [pomodlić]. Pochodziła z Wałbrzycha, więc nie wiedziała, po co się przychodziło [do katedry] ${ }^{94}$. Autentycznie przyszła się pomodlić, bo wcześniej była u lekarza i miała trochę czasu do następnego pociągu. Zaczęli [milicjanci] nazywać ją starą wroną i rozbili jej głowę - kobieta leżała tam, kurczę, i nikt się nią nie interesował, bo mówią, że to stara wrona. Nie wiem skąd [im się to wzięło], bo wrona to przecież było wtedy najbardziej obraźliwe słowo w tym czasie ${ }^{95}$, a ją tak nazywali starą wroną. Bo rzeczywiście była starsza może kobieta i miała chyba czarne włosy. Nie wiem, czy ją traktowali poważnie, ale ja jestem przekonany, że ona to, co mówiła, to mówiła prawdę. Jakiś facet dostał tam też jakiejś zapaści, ale nikt się tym nie interesował, bo kto dostał swoje pały, to dostał. No i powieźli ludzi na kolegium ${ }^{96}$ - każdy dostał, znaczy nie wiem, czy każdy, bo to były kolegia niezależne i jeden z drugim nie mógł się skontaktować. Przy zarobkach [średnich] załóżmy jakichś 8 tysięcy, to ludzie podostawali kolegium od 30 do 60 tysięcy złotych - proszę sobie wyobrazić, jakie to były ogromne pieniądze dla tych ludzi. Dobrze, że gdzieś tam się zorganizowało pieniądze od ludzi, którzy [je] zebrali. Bo przecież zarobki w tym czasie to starczały tylko, jak to niektórzy tłumaczyli, starczyło ci na jedno jajko dziennie, tak to mniej więcej wyglądało. Że dwa to już było za dużo, bo za dużo [człowiek] cholesterolu by zjadł [śmiech]. Takie to były czasy, że zarabiało się 10-15 dolarów. Potrafili takie kolegia walić i nikt się nad tym nie zastanawiał, z czego ci ludzie mogą zebrać. Ale niestety trzeba było zapłacić, bo jakbyś nie zapłacił, to by cię, kurczę... No to zamieniliby ci na areszt.

94 W tym czasie msze za Ojczyznę były popularnym sposobem manifestowania sprzeciwu wobec władz komunistycznych i uczęszczali na nie również ludzie niewierzący. Tradycję mszy we wrocławskiej katedrze zapoczątkował arcybiskup Henryk Gulbinowicz już 16 XII 1981 r.; W. Suleja, op. cit., s. 146.

95 Chodzi o obraźliwą modyfikację akronimu Wojskowej Rady Ocalenia Narodowego (WRON-a), którą wykorzystywano w skierowanych przeciw władzy hasłach i rymowankach pisanych m.in. na murach.

96 Kolegium ds. wykroczeń działało od 1951 do 2001 r. jako pozasądowy organ orzekający w sprawach o wykroczenia; zob. A. Marek, Prawo wykroczeń (materialne i procesowe), Warszawa 2008. 
[...] Dumny z siebie [i ze swojej działalności opozycyjnej] może nie jestem [śmiech], ale uważam, że to [co robiłem] było słuszne i jestem zadowolony, że ta komuna upadła. Ale faktem [jest], że nie wszyscy na tym zyskali, bo wielu ludzi, kolegów, którzy walczyli tam, naprawdę nie zostało docenionych, ludzie, którzy, kurczę, w manifestacjach stracili zdrowie. Chłopak, któremu strzelali w nogi ${ }^{97}$, to $\mathrm{w}$ stanie wojennym miał bardzo trudną sytuację, nie bardzo mu mogli ludzie mu pomóc - [udało] się trochę przez Kościół, bo tam pomagali. Ale naprawdę jeżeli chodzi o tych ludzi, którzy zostali mocno pokrzywdzeni - stracili [zdrowie], pracę, to gdyby chcieli zrobić bilans zysków i strat, to moim zdaniem oni stracili. Natomiast ja uważam to za przygodę i poza tym na pewno w jakimś tam stopniu przyczyniliśmy się również do tego, że ta komuna upadła. Bo nie tylko ludzie typu Frasyniuk, bo ten jak mocniej kaszlnął w więzieniu, to cała Europa na ten temat mówiła. Natomiast ci ludzie tacy „bezimienni” rzeczywiście oddawali bardzo dużo i o nich praktycznie się zapomniało - i tu jest właśnie żal do tych przywódców, że rzeczywiście nie wykorzystali szans, bo tym ludziom naprawdę było trzeba pomóc i oni mają naprawdę duży żal do tych przywódców, bo oni gdzieś tam przy okazji swoje rzeczy załatwili, zgarnęli stanowiska i teraz żyją sobie nawet godnie. Natomiast wielu ludzi potraciło pracę przy tych reorganizacjach, przy tych, kurczę, prywatyzacjach i w związku z tym, że przyglądali się temu, widzą, że ta Polska - nie wszyscy się z tym zgodzą - naprawdę została rozkradziona. [...] Może być, że to jest dobre, bo prawo prawem, ale, kurczę, nie było ludzi, którzy by dopilnowali tego tak, jak to się powinno robić. Zakłady pracy, które zostały sprywatyzowane - w mojej perspektywie, którą ja widzę - to praktycznie żaden nie został sprywatyzowany we właściwy sposób. Komuniści, którzy byli dyrektorami w tym czasie w zakładach pracy, po prostu najczęściej w ten sposób przechwycili majątek, sprywatyzowali się, później to przekręcili jeszcze raz, sprzedali i w tej chwili to oni mają pieniądze i oni mają wpływy na wszystko. Oczywiście część ludzi [postąpiła] uczciwie, [ta] która kupiła. Natomiast ci, którzy to sprzedawali, to łącznie z tymi likwidatorami przedsiębiorstw, ci, którzy w urzędach wojewódzkich wtedy pracowali, to wszyscy ludzie... No może przesadzam, że wszyscy, ale w 90\% zostało to po prostu w niewłaściwy

97 Osoba bliżej nieznana. 
sposób sprywatyzowane, zostało to wręcz rozkradzione ${ }^{98}$. I nie ma się co dziwić, że ci ludzie [opozycjoniści] słuchają dziś Radia Maryja, bo tam o tym się mówi. Natomiast ogólnie to się mówi, że wszystko je ok, bo po to jest prokuratura, bo po to są sądy i jeszcze inne instytucje, które mogą się tymi sprawami zajmować, ale te instytucje są po prostu umoczone i tak to wszystko wygląda. Tak że satysfakcję z tego, że komuna upadła, tacy ludzie mają, ale że majątek przeszedł w ręce ludzi, którzy praktycznie wcześniej mieli wpływ na to, to już jest wina naszych władz. [...] Ale prawo nie działało tak [jak powinno], prawo działało na korzyść tych właśnie rozkradających, a nie tych, którzy rzeczywiście walczyli.

98 Tę opinię przynajmniej w części potwierdza raport Najwyższej Izby Kontroli z 2010 r.; zob.: Informacja o wynikach działalności likwidatorów oraz dofinansowania z Funduszu Skarbu Państwa procesów likwidacji przedsiębiorstw państwowych, KGP-410-16-/2009, Warszawa 2010. 
Adamczewski G., Radio Wolna Europa w okresach politycznych przełomów, Wrocław 2011.

Białkowski K., Człowiek, który zatrzymat Wrocław: https://www.gosc.pl/doc/1673297.Czlowiekktory-zatrzymal-Wroclaw.

Biernacki L., Kazański A., NSZZ „Solidarność” Region Gdański, [w:] NSZZ „Solidarnośc” 1980 -1989. T. 3, Polska pótnocna, red. Ł. Kamiński, G. Waligóra, Warszawa 2010.

Bosacka M., Czasopisma drugiego obiegu w zbiorach Biblioteki Uniwersyteckiej we Wroctawiu, „Bibliotheca Nostra. Śląski kwartalnik naukowy”, nr 2 (2013), s. 64-76.

Cenzura w PRL. Relacje historyków, red. Z. Romek, Warszawa 2010.

Chinciński T., Jutro wolna sobota, „Biuletyn Instytutu Pamięci Narodowej”, nr 10 (2003), s. 53-56.

Dombska A., Ograniczenia wolności prasy w PRL, „Studia Prawno-Ekonomiczne”, t. LXXXIV (84) (2011), s. 79-100.

Dworaczek K., Podziemne drukarstwo we Wroctawiu na przykładzie największych inicjatyw wydawniczych, „Dzieje Najnowsze”, t. 48, nr 4 (2016), s. 141-155.

Eisler J., Polskie miesiace, czyli kryzys(y) w PRL, Warszawa 2008.

Grzelczyk K., Solidarność drukujaca. Wrocławscy drukarze podziemni, Wrocław 2013.

Hajdasz J., Szczekaczka, czyli Rozgtośnia Polska Radia Wolna Europa, Poznań 2006.

Johnson A.R., Radio Free Europe and Radio Liberty. The CIA years and beyond, Washington 2015.

Kamiński Ł., Dekada „Solidarności”, „Biuletyn Instytutu Pamięci Narodowej”, nr 9-10 (2010), S. $2-13$.

Kamiński Ł., Krasnoludki i żotnierze. Wrocławska opozycja lat osiemdziesiatych, „Pamięć i Przyszłość", nr 2 (2008), s. 6-19.

Kamiński Ł., Piotrowski P., Dolny Ślask $i$ Ślask Opolski, [w:] Stan wojenny w Polsce 1981-1983, red. A. Dudek, Warszawa 2003, s. 27-86.

Kazański A., Sierpień '8o w Gdańsku, „Biuletyn Instytutu Pamięci Narodowej”, nr 9-10 (2010), S. 21-34.

Kazański A., Sierpień '8o w Gdyni, „Biuletyn Instytutu Pamięci Narodowej”, nr 9-10 (2010), s. 45-56.

Kordas J., Wydarzenia 31 sierpnia 1982 r. na Dolnym Ślasku. Geneza, przebieg, skutki, Wrocław 2010.

Korejwo M., Próba systematyzacji podstawowych ogniw PZPR na podstawie olsztyńskiej wojewódzkiej organizacji partyjnej, „Komunizm: system - ludzie - dokumentacja”, nr 1 (2012), s. 101-110.

Kozłowski T., Droga do rejestracji, „Biuletyn Instytutu Pamięci Narodowej”, nr 9-10 (2010), S. $98-103$.

Kozłowski T., Olaszek J., Internowani w stanie wojennym. Dane statystyczne, „Pamięć i Sprawiedliwość", 9/2 (2010), s. 501-510. 
Kucharski W., Centrum Historii Zajezdnia we Wrocławiu. Albo: jak porwać opowieścia o historii miasta, https://wszystkoconajwazniejsze.pl/wojciech-kucharski-centrum-historii-zajezdnia-we-wroclawiu-albo-jak-porwac-opowiescia-o-historii-miasta/.

Krupski T., Wtadza komunikuje się ze społeczeństwem. Jerzy Urban i jego konferencje prasowe dla dziennikarzy zagranicznych, [w:] Opozycja i opór społeczny w Polsce po 1956 roku, t. 2, red. T. Kozłowski, J. Olaszek, Warszawa 2014, s. 234-280.

Łęcicki G., Cenzura w Polsce Ludowej: propaganda, manipulacja, destrukcja, „Kwartalnik Nauk o Mediach", nr 2 (2015), http://knm.uksw.edu.pl/cenzura-w-polsce-ludowej-propaganda-manipulacja-destrukcja/.

Magier D., Podstawowe organizacje partyjne w systemie biurokratycznym Polskiej Zjednoczonej Partii Robotniczej, [w:] Dzieje biurokracji, t. 4, red. A. Górak, K. Latawiec, D. Magier, Lublin -Siedlce 2011, s. 783-799.

Marek A., Prawo wykroczeń (materialne i procesowe), Warszawa 2008.

Nowak L., Polska droga od socjalizmu. Pisma polityczne 1980-1989, [w:] Studia i materiaty poznańskiego IPN, t. XVII, red. K. Brzechczyn, Poznań 2011, s. 428-452.

Olaszek J., Dokumenty Stużby Bezpieczeństwa jako źródto do badania historii prasy podziemnej (wybrane przyktady), [w:] Letnia Szkota Historii Najnowszej 2010. Referaty, red. N. Jarska, T. Kozłowski, Warszawa 2011, s. 227-238.

Olaszek J., Podziemne dziennikarstwo. Funkcjonowanie głównych pism informacyjnych podziemnej „Solidarności” w Warszawie w latach 1981-1989, Warszawa 2018.

Olaszek J., Wołk G., Drugi obieg wydawniczy w oczach Stużby Bezpieczeństwa, „Pamięć i Sprawiedliwość", nr 1 (2013), s. 369-435.

Paczkowski A., Stan wojenny i „powojenny”: od grudnia 1981 do stycznia 1989, [w:] Polski wiek $X X$, t. 4, red. K. Persak, P. Machcewicz, Warszawa 2011, s. 207-230.

Paczkowski A., Wojna polsko-jaruzelska. Stan wojenny w Polsce 13 XII 1981 - 22 VII 1983, Warszawa 2006.

Polak W., Internowania w nocy z 12 na 13 grudnia 1981, „Biuletyn Instytutu Pamięci Narodowej”, nr 11-12 (2011), s. 91-98.

Polak W., Od dziecięcej drukarenki do offsetu. Krótka historia niezależnej poligrafii w Toruniu, „Biuletyn Instytutu Pamięci Narodowej”, nr 7 (2002), s. 70-81.

Pszenicki K., Tu mówi Londyn. Historia sekcji Polskiej BBC, Warszawa 2009.

Puddington A., Broadcasting Freedom. The Cold War Triumph of Radio Free Europe and Radio Liberty, Lexington 2000.

Ruciński A., Instytucje medialne w okresie stanu wojennego, „Przegląd Prawniczy, Ekonomiczny i Społeczny", nr 2 (2013), s. 56-71.

Rydz B., Organizacja terenowych struktur zwiąków zawodowych w potudniowych powiatach województwa lubelskiego w latach 1944-1975, „Radzyński Rocznik Humanistyczny”, t. 10 (2012), s. 92-101. Sasanka P., Czerwiec 1976. Geneza, przebieg, konsekwencje, Warszawa 2006. 
Sikkora M.O., Prasa gdańska w stanie wojennym (1981-1983). Przeglad problemowy, „Acta Cassubiana", nr 12 (2010), s. 123-162.

Sołtysik Ł., Solidarność w „Polarze”, Wrocław 2016.

Stan wojenny w Polsce. Kalendaria wydarzeń 13 XII 1981 - 31 XII 1982, red. W. Chudzik, Warszawa 1999.

Strzyżewski T., Wielka księga cenzury PRL w dokumentach, Warszawa 2015.

Suleja W., „Solidarność” na Dolnym Ślasku 1980-2010, Wrocław 2010.

Szwagrzyk K., Naczelnicy więzienia przy ul. Kleczkowskiej we Wrocławiu 1945-1955, „Biuletyn Instytutu Pamięci Narodowej", nr 6 (2002), s. 55-58.

Urbaniak P., Literackie pisma bezdebitowe we Wroctawiu w latach 1976-1989, „Rocznik Historii Prasy Polskiej", t. 14 (2011), zeszyt 1-2, s. 189-205.

Waligóra G., Opozycja polityczna na Dolnym Śląsku 1975-198o, Wrocław 2016.

Wanke-Jakubowska M., Wanke-Jerie M., Pro memoria. Bohaterowie Solidarności Walczacej, Wrocław 2017.

Webb A., London calling. Britain, the BBC World Service, and the Cold War, London 2015.

Wolniewicz Ł., Historia tramwajów we Wrocławiu 1945-2015, wykład: https://wroclawskakomunikacja.pl/biezace-wiadomosci/54-aktualnosci/1167-historia-tramwajow-we-wroclawiu-1945-2015-wyklad.

Zakrzewski W., O ingerencji prawodawczej w wolność słowa w okresie PRL, „Studia Iuridica Lublinensia", nr 22 (2012), s. 631-655.

Zblewski Z., Czym byty milicyjne „ścieżki zdrowia”? Przypominamy relację z pierwszej ręki: https://twojahistoria.pl/2018/o2/o3/czym-byly-milicyjne-sciezki-zdrowia-przypominamy-relacje-z-pierwszej-reki/\#2.

Ziątkowski L., Na drodze do Solidarności. Wrocław w walce o demokrację i niepodległość 19761980, Wrocław 2010.

Ziątkowski L., Na drodze do wolności. Solidarny Wrocław sierpień 1980 - grudzień 1981, Wrocław 2011. 
Marcin Adamczyk

"Beware of the Bomb!": An Account
Jerzy Adamczyk's narrative was recorded in the middle of the last decade in the form of an audio file (currently in the author's possession) at the request of his family. However, it has been edited to coincide with the tenth anniversary of the death of this witness to history, who was one of the members of Fighting Solidarity and the co-founder of its "Feniks" Independent Workers' Publishing House. From Adamczyk's recollections, we can learn a lot about how the introduction of martial law in Wroctaw was viewed from the perspective of the socalled intellectual worker; about how great a challenge creating a free trade union from scratch in a non-productive establishment was; and, finally, about how those days were at times ridiculous and other times dramatic. The bitter reflections of Jerzy Adamczyk on the political and economic situation of Poland at the beginning of the twenty-first century appear as a summation of his narrative.

Keywords: Fighting Solidarity, martial law, "Feniks" Independent Workers' Publishing House 